\title{
The Relationship between Financial Development and Economic Growth during the recent Crisis: Evidence from the EU
}

\begin{abstract}
This paper aims to examine the relationship between financial development and economic growth on the face of the recent financial crisis, using a panel dataset of 26 European Union countries over the period 1990-2016. The empirical approach uses multiplicative dummies to compare two distinct sub-periods before/after the crisis. The results show that before crisis, financial development promoted economic growth, while after the crisis it hindered economic activity. Also, the findings suggest that during the years 2008 and 2009 the capital adequacy of banks protected depositors and promoted the stability of the financial system.
\end{abstract}

Keywords: Economic growth; Financial development; Panel data; Dummy variables; Fixed effects. 


\section{Introduction}

The impact of financial development on economic growth has received a considerable investigation in the empirical literature. Although cross-sectional studies concluded that financial development positively affects economic growth (?Levine and Zervos, 1996; Levine, 1997; Azman-Saini et al., 2010), empirical studies that used time-series or panel data models arrived at a less uniform conclusion (Arestis et al., 2001; Demetriades, 1996; Levine, 1999; Caporale et al., 2015; Samargandi et al., 2015; Bumann et al., 2013).

Also, there is evidence that time-series studies where one country is examined, either developed or developing, concluded in unidirectional causality results. In particular, in a recent study Shahbaz et al. (2015) examined the financial development and economic growth nexus in a developing country, and the findings suggest that the development of financial sector facilitates economic growth, trade openness stimulates the economic activity, but for real capital, this is not true. The results also show that both, financial development and trade openness are significant driving forces for growth in the long run (Shahbaz, 2012).

Furthermore, in a more recent study, Shahbaz et al. (2017) investigated the drivers of economic growth in China and India using annual data over the period 1970-2013, and the results indicate that financial development increases economic activity in those two countries. Interestingly, in a different study, Andreasen and Valenzuela (2016) found that financial openness has a positive effect on credit ratings and the primary mechanism behind this effect is the domestic financial development.

However, although the literature is extensively vast so far, to the best of our knowledge, no study has attempted to compare the financial development conventional measures that led to economic growth across the European Union (EU) countries, before, during and after the recent financial crisis in 2008. The paper contributes in three different angles. First, it examines the effect of financial development in two phases of crisis periods; the sub-prime period ${ }^{1}$ and the ongoing crisis period ${ }^{2}$. Second, it provides an investigation of the panel heterogeneity by presenting results of three different regional groups. Third, it extends the literature regarding the relationship between financial development and economic growth through a comparative

\footnotetext{
${ }^{1}$ The sub-prime crisis period (2008-2009) refers to the crisis that occurred in the mortgage industry due to borrowers being approved for loans they could not repay.

${ }^{2}$ Here, the assumption is that the financial crisis is ongoing which is true for most EU countries and hence the dummy is defined for the whole period from 2008 to 2016
} 
approach on the face of the recent financial crisis in a group of countries that implement the same regulations for the financial sector.

The following section includes a description of data and section 3 presents the model specification. Section 4 provides the empirical results and discussion, while section 5 concludes.

\section{Data}

The empirical analysis uses annual data for 26 European Union countries $(\mathrm{N}=26)$ over the period 1990 to 2016 ( $\mathrm{T}=27)$. All data are obtained from the Global Financial Development Database published by the World Bank ${ }^{3}$.

Summary statistics are presented in Table 1. It is worth noticing that the coefficients of variation $(\mathrm{CV})$ are relatively small in financial development measures and trade openness indicating that are less dispersed than the rest of the variables. The ratio of bank assets BTOT has the smallest coefficient of variation, and a sample mean equal to $96 \%$, implying the advantage of financial institutions in challenging savings. Also, trade openness OPEN has a sample mean equal to 92 approximately, suggesting a large dependence on trade for the EU countries.

Table 1: Summary statistics

\begin{tabular}{|c|c|c|c|c|c|c|}
\hline variables & Obs. & Mean & Max & Min & Std.Dev. & CV \\
\hline$G G D P$ & 694 & 1.937 & 11.889 & -34.900 & 4.296 & 2.217 \\
\hline$L L Y$ & 688 & 71.426 & 258.033 & 7.867 & 37.421 & 0.523 \\
\hline BTOT & 681 & 96.078 & 107.140 & 40.763 & 8.513 & 0.088 \\
\hline$M C A P$ & 623 & 45.024 & 238.844 & 0.025 & 38.319 & 0.851 \\
\hline TOR & 614 & 53.746 & 341.236 & 0.027 & 46.205 & 0.856 \\
\hline$I N F L$ & 681 & 9.617 & 958.646 & -9.679 & 45.632 & 4.741 \\
\hline$F D I$ & 637 & 9.483 & 734.00 & -43.462 & 42.261 & 4.456 \\
\hline OPEN & 702 & 92.120 & 221.157 & 33.00 & 37.806 & 0.41 \\
\hline \multicolumn{7}{|c|}{$\begin{array}{l}\text { liabilities to GDP. BTOT is the ratio of commercial bank assets to the sum of commercial } \\
\text { bank plus central bank assets. } M C A P \text { is the stock market capitalisation to GDP. TOR is the } \\
\text { stock market turnover ratio. INFL is the inflation rate. FDI is the net inflows of foreign direct }\end{array}$} \\
\hline
\end{tabular}

\footnotetext{
${ }^{3}$ See Appendix A for detailed description of data
} 


\section{Model specification}

To analyse the financial development measures that led to economic growth before the crisis and those of which led to economic growth during both periods of crisis, we employ various panel regressions. The basic econometric benchmark model, is as below:

$$
G G D P_{i t}=\alpha_{0}+\boldsymbol{\beta}^{\prime} \boldsymbol{F} \boldsymbol{D}_{i t}+\gamma^{\prime} \boldsymbol{X}_{i t}+u_{i t}
$$

where the dependent variable is $G G D P, i$ and $t$ subscripts are defined as $i=1,2, \ldots, 26$ EU countries and $t=1990, \ldots, 2016$. Then, $\alpha_{0}$ denotes the intercept; $\boldsymbol{\beta}$ and $\boldsymbol{\gamma}$ are the vectors of coefficients; $\boldsymbol{F} \boldsymbol{D}_{\boldsymbol{i t}}$ is a matrix of financial development measures (LLY, BTOT, MCAP, TOR); $\boldsymbol{X}_{\boldsymbol{i t}}$ is a matrix of control variables (INFL, FDI, OPEN) and $u_{i t}$ captures an error term.

Given that the primary purpose is to investigate the impact of financial development on economic growth through a comparative approach before/after crisis, we use in the above model two dummy variables; one for the sub-prime crisis period (years 2008 and 2009); and one for the ongoing crisis period (years 2008 to 2016).

The Hausman test was used in order to decide between fixed effects (FE) and random effects (RE) estimates, under the full set of random effects assumptions. The results from the test suggest that the RE assumption is rejected; therefore the FE estimates are used.

Based on Brambor et al. (2005), in interactive regressions the overall impact can be estimated by calculating the net effects ${ }^{4}$ under conditional hypotheses. In particular, an increase in $X$ is associated with an increase/decrease in $Y$, while $Z$ is a dichotomous variable that is equal to one when the required condition is met, and zero otherwise (when condition $Z$ is absent). To see this, the following model is presented:

$$
Y=\beta_{0}+\beta_{1} X+\beta_{2} X Z+u_{i t}
$$

It is obvious to see that the model presented in Eq. (2) captures the effect of one unit change in $X$ on $Y$ when condition $Z$ is absent $(Z=0)$, which is $\beta_{1}\left(\partial Y / \partial X=\beta_{1}\right)$. When condition $\mathrm{Z}$ is present $(Z=1)$ the effect of one unit change in $X$ on $Y$ is $\beta_{1}+\beta_{2}\left(\partial Y / \partial X=\beta_{1}+\beta_{2}\right)$.

\footnotetext{
${ }^{4}$ The net effects approach we follow has been used extensively in economic studies such as Asongu and Nwachukwu (2018), Tchamyou and Asongu (2017), Asongu et al. (2017).
} 


\section{Estimation results and Discussion}

\subsection{Overall results}

The results from the full panel of countries are reported in Table 2. The first two models, present the results from the whole sample period. We find that the ratio of commercial bank assets and market capitalisation have a positive and statistically significant impact on economic growth, while the other financial development variables are insignificant.

In models III and IV, we find that in the pre-ongoing crisis period the ratio of commercial bank assets, market capitalisation and turnover ratio have a positive and statistically significant impact on economic growth, while liquid liabilities is insignificant. During the ongoing crisis period the only statistically significant variable is the turnover ratio which has a negative effect on economic growth.

In the last two models, when the subprime crisis period is not included in the model (V), we find similar results to those in the pre-ongoing crisis period. During the subprime crisis period (model VI) the ratio of commercial bank assets has a positive and significant impact on economic growth with a remarkable great value (approximately 9\%), while liquid liabilities is negatively related to economic growth and statistically significant.

Interestingly, INF and FDI are negative and significant during the ongoing crisis, while $I N F$ is negative and significant for the subprime crisis as well. OPEN is the only positive and significant driving force of growth during both crisis periods.

The nets effects based on conditional and unconditional effects are estimated from the interaction between crisis dummy and financial development variables. For example, in the interactive regression $(\mathrm{V})$ column five, the net effects for the interaction between BTOT and crisis dummy is $9.302(0.192+9.11)$. The unconditional effect of BTOT is 0.192 , while the conditional is 9.11. The results are positive for BTOT and $M C A P$ across all interactive regressions, while the net effects of the size of bank sector $(L L Y)$ and the liquidity of market sector (TOR) are negative in interactive models V,VI and III,IV respectively. 
Table 2: Full sample of countries

\begin{tabular}{|c|c|c|c|c|c|c|}
\hline \multirow{2}{*}{$\frac{\text { period }}{\text { Variables }}$} & \multicolumn{2}{|c|}{ whole sample } & \multicolumn{2}{|c|}{ ongoing crisis $\mathrm{Cr}=\mathrm{Cr} 0816$} & \multicolumn{2}{|c|}{$\underline{\text { subprime } \text { crisis } \mathrm{Cr}=\mathrm{Cr} 0809}$} \\
\hline & model (I) & model (II) & model (III) & model (IV) & model (V) & model (VI) \\
\hline \multirow[t]{2}{*}{ cons } & $1.94 * * *$ & $2.07^{* * *}$ & $1.914^{* * *}$ & $2.20^{* * *}$ & $2.00^{* * *}$ & $2.280^{* * *}$ \\
\hline & {$[7.94]$} & {$[3.41]$} & {$[3.72]$} & {$[3.52]$} & {$[3.76]$} & {$[9.93]$} \\
\hline \multirow[t]{2}{*}{$D(L L Y)$} & -0.08 & -0.100 & -0.030 & -0.018 & -0.014 & 0.018 \\
\hline & {$[-1.47]$} & {$[-1.18]$} & {$[-1.51]$} & {$[-0.62]$} & {$[-0.43]$} & {$[0.73]$} \\
\hline \multirow[t]{2}{*}{$D(B T O T)$} & $0.273^{* *}$ & $0.237^{* *}$ & $0.198^{* * *}$ & $0.145^{* *}$ & $0.192^{* * *}$ & $0.158^{* *}$ \\
\hline & {$[2.73]$} & {$[2.65]$} & {$[3.24]$} & {$[2.68]$} & {$[2.97]$} & {$[2.44]$} \\
\hline \multirow[t]{2}{*}{$D(M C A P)$} & $0.041^{* *}$ & $0.037^{* * *}$ & $0.025^{* *}$ & $0.026^{* * *}$ & $0.020^{*}$ & $0.024^{* * *}$ \\
\hline & {$[2.54]$} & {$[3.41]$} & {$[2.62]$} & {$[2.80]$} & {$[1.97]$} & {$[2.70]$} \\
\hline \multirow[t]{2}{*}{ TOR } & 0.007 & 0.007 & $0.016^{* * *}$ & $0.015^{* * *}$ & $0.010^{* *}$ & $0.010^{* * *}$ \\
\hline & {$[1.49]$} & {$[1.48]$} & {$[3.10]$} & {$[3.21]$} & {$[2.07]$} & {$[2.77]$} \\
\hline \multirow[t]{2}{*}{$I N F L$} & & -0.020 & & -0.031 & & $-0.027^{* *}$ \\
\hline & & {$[-0.91]$} & & {$[-1.54]$} & & {$[-2.29]$} \\
\hline \multirow[t]{2}{*}{$F D I$} & & -0.001 & & 0.00007 & & -0.001 \\
\hline & & {$[-0.60]$} & & {$[0.06]$} & & {$[-055]$} \\
\hline \multirow[t]{2}{*}{$D(O P E N)$} & & 0.032 & & 0.0013 & & $-0.021 *$ \\
\hline & & {$[0.79]$} & & {$[0.08]$} & & {$[-1.78]$} \\
\hline \multirow[t]{2}{*}{$C r^{*} D(L L Y)$} & & & -0.149 & -0.112 & $-0.570^{* * *}$ & $-0.474^{* * *}$ \\
\hline & & & {$[-0.97]$} & {$[-0.80]$} & {$[-7.42]$} & {$[-6.57]$} \\
\hline \multirow[t]{2}{*}{$C r^{*} D(B T O T)$} & & & -0.171 & 0.004 & $9.11^{* * *}$ & $8.60^{* * *}$ \\
\hline & & & {$[-0.77]$} & {$[0.002]$} & {$[5.15]$} & {$[5.15]$} \\
\hline \multirow[t]{2}{*}{$C r^{*} D(M C A P)$} & & & 0.010 & -0.017 & -0.009 & -0.031 \\
\hline & & & {$[0.50]$} & {$[-1.15]$} & {$[-0.68]$} & {$[-1.42]$} \\
\hline \multirow[t]{2}{*}{$C r^{*} T O R$} & & & $-0.023^{* * *}$ & $-0.019^{* * *}$ & -0.0003 & 0.002 \\
\hline & & & {$[-4.63]$} & {$[-4.57]$} & {$[-0.11]$} & {$[0.39]$} \\
\hline \multirow[t]{2}{*}{$C r^{*} I N F L$} & & & & $-0.400^{* *}$ & & $-0.307 * * *$ \\
\hline & & & & {$[-2.52]$} & & {$[-3.19]$} \\
\hline \multirow[t]{2}{*}{$C r^{*} F D I$} & & & & $-0.004^{*}$ & & 0.017 \\
\hline & & & & {$[-1.80]$} & & {$[1.26]$} \\
\hline \multirow[t]{2}{*}{$C r^{*} D(O P E N)$} & & & & $0.134^{* *}$ & & $0.293^{* * *}$ \\
\hline & & & & {$[2.11]$} & & {$[7.27]$} \\
\hline \multicolumn{7}{|l|}{ net effects } \\
\hline$l l y$ & & & n.a & n.a & -0.407 & -0.338 \\
\hline btot & & & 0.198 & 0.145 & 8.938 & 8.414 \\
\hline mcap & & & 0.025 & 0.026 & 0.020 & 0.024 \\
\hline tor & & & -0.014 & -0.011 & 0.0054 & 0.0054 \\
\hline$R^{2}$ & 0.082 & 0.096 & 0.177 & 0.244 & 0.234 & 0.326 \\
\hline obs & 596 & 567 & 596 & 567 & 596 & 567 \\
\hline
\end{tabular}

Note: Had cross-sectional dependence be present, the results have been obtained by using Driscoll and Kraay (1998) standard errors estimates that are robust to disturbances being heteroscedastic, auto correlated and cross sectional dependent. Dependent variable is the GGDP. The numbers in brackets denote t-statistics. $(* * *),(* *),(*)$ reflect the $1 \%, 5 \%, 10 \%$ level of significance respectively. $D$ denotes the first difference for the variables $L L Y, B T O T, M C A P$ and $O P E N$ that were transformed to become stationary. Panel unit root test was executed to test the stationarity. $\mathrm{Cr}$ stands for the crisis dummy. Model (I) includes the financial development measures, while model (II) includes the financial development measures and the control variables. Model (III) includes the financial development measures and their interaction with crisis dummy (Cr0816), while model (IV) includes interactions with the control variables as well. Model V and VI are defined similarly to the ongoing crisis with crisis dummy (Cr0809). 


\subsection{Regional results}

It is necessary to divide the full panel of $26 \mathrm{EU}$ countries into smaller regional panels (see Appendix A data description) that are more homogeneous in terms of level of financial development. Table 3 presents the results from the regional panels.

Table 3: Regional results

\begin{tabular}{|c|c|c|c|c|c|c|c|c|c|}
\hline \multirow{3}{*}{$\begin{array}{l}\text { Panel } \\
\text { period } \\
\end{array}$} & \multicolumn{3}{|c|}{ A: North-West EU countries } & \multirow{2}{*}{\multicolumn{3}{|c|}{$\frac{\text { B: Central-Eastern EU countries }}{\text { Transition economies }}$}} & \multicolumn{3}{|c|}{ C: South EU countries } \\
\hline & \multirow{3}{*}{$\begin{array}{l}\text { whole } \\
\text { sample }\end{array}$} & \multirow{3}{*}{$\begin{array}{l}\frac{\text { ongoing }}{\mathrm{Cr}=\mathrm{Cr} 0816} \\
\underline{\underline{n}}\end{array}$} & \multirow{3}{*}{$\begin{array}{l}\underline{\text { sub-prime }} \\
\underline{\mathrm{Cr}=\mathrm{Cr} 0809}\end{array}$} & & & & \multirow{3}{*}{$\frac{\text { whole }}{\text { sample }}$} & \multirow[b]{2}{*}{ ongoing } & \multirow[b]{2}{*}{ sub-prime } \\
\hline & & & & \multirow{2}{*}{$\frac{\text { whole }}{\text { sample }}$} & \multirow{2}{*}{$\begin{array}{l}\frac{\text { ongoing }}{\mathrm{Cr}=\mathrm{Cr} 0816} \\
\underline{ }\end{array}$} & \multirow{2}{*}{$\begin{array}{l}\underline{\text { sub-prime }} \\
\mathrm{Cr}=\mathrm{Cr} 0809\end{array}$} & & & \\
\hline & & & & & & & & $\overline{\mathrm{Cr}=\mathrm{Cr} 0816}$ & $\mathrm{Cr}=\mathrm{Cr} 0809$ \\
\hline Variables & $\overline{\text { model }}(\mathrm{I})$ & model (II) & model (III) & $\overline{\operatorname{model}}(\mathrm{IV})$ & model (V) & model (VI) & $\overline{\operatorname{model}}(\mathrm{VII})$ & model (VIII) & model (IX) \\
\hline \multirow[t]{2}{*}{ cons } & 0.805 & 0.586 & 1.157 & $2.627^{* *}$ & $3.589^{* * *}$ & $3.605^{* * *}$ & -0.770 & -0.275 & -0.233 \\
\hline & {$[1.10]$} & {$[0.77]$} & {$[1.80]$} & {$[3.06]$} & {$[4.34]$} & {$[4.35]$} & {$[-0.59]$} & {$[-0.24]$} & {$[-0.18]$} \\
\hline \multirow[t]{2}{*}{$D(L L Y)$} & -0.084 & -0.024 & 0.049 & -0.315 & 0.076 & -0.012 & 0.029 & 0.028 & 0.140 \\
\hline & {$[-1.03]$} & {$[-0.66]$} & {$[0.87]$} & {$[-1.36]$} & {$[0.88]$} & {$[-0.23]$} & {$[1.038]$} & {$[0.29]$} & {$[1.62]$} \\
\hline \multirow[t]{2}{*}{$D(B T O T)$} & 0.066 & 0.041 & 0.075 & $0.316^{* *}$ & $0.164^{*}$ & $0.218^{* *}$ & $0.625^{* * *}$ & $0.467^{* * *}$ & $0.559^{* *}$ \\
\hline & {$[0.55]$} & {$[0.49]$} & {$[0.75]$} & {$[2.75]$} & {$[1.95]$} & {$[3.02]$} & {$[2.96]$} & {$[3.57]$} & {$[2.75]$} \\
\hline \multirow[t]{2}{*}{$D(M C A P)$} & $0.048^{* *}$ & $0.040^{* * *}$ & $0.026^{*}$ & 0.036 & 0.0008 & 0.008 & 0.044 & 0.016 & 0.036 \\
\hline & {$[2.43]$} & {$[3.35]$} & {$[2.00]$} & {$[1.28]$} & {$[0.02]$} & {$[0.27]$} & {$[1.46]$} & {$[1.17]$} & {$[1.30]$} \\
\hline \multirow[t]{2}{*}{ TOR } & 0.011 & $0.022^{* *}$ & $0.017^{* *}$ & 0.007 & -0.002 & -0.0013 & $0.010^{* *}$ & $0.012^{* *}$ & $0.010^{* *}$ \\
\hline & {$[1.53]$} & {$[3.06]$} & {$[2.44]$} & {$[0.93]$} & {$[-0.42]$} & {$[-0.16]$} & {$[2.76]$} & {$[2.42]$} & {$[2.43]$} \\
\hline \multirow[t]{2}{*}{$I N F L$} & 0.111 & 0.076 & -0.141 & $-0.030^{*}$ & $-0.032^{* *}$ & -0.024 & $0.307^{* *}$ & 0.216 & 0.230 \\
\hline & {$[0.43]$} & {$[0.25]$} & {$[-0.92]$} & {$[-2.22]$} & {$[-2.37]$} & {$[-1.60]$} & {$[2.19]$} & {$[1.41]$} & {$[1.57]$} \\
\hline \multirow[t]{2}{*}{$F D I$} & -0.002 & -0.002 & -0.003 & $0.126^{* * *}$ & $0.116^{* *}$ & $0.115^{* * *}$ & $-0.015^{* *}$ & $0.261^{* *}$ & $-0.016^{* *}$ \\
\hline & {$[-0.87]$} & {$[-1.52]$} & {$[-1.64]$} & {$[3.54]$} & {$[2.38]$} & {$[3.34]$} & {$[-2.10]$} & {$[2.73]$} & {$[-2.50]$} \\
\hline \multirow[t]{2}{*}{$D(O P E N)$} & $0.127^{* * *}$ & $0.095^{*}$ & 0.089 & 0.082 & 0.038 & -0.036 & 0.133 & $0.162^{* *}$ & 0.062 \\
\hline & {$[3.64]$} & {$[2.11]$} & {$[1.70]$} & {$[1.76]$} & {$[1.23]$} & {$[-0.76]$} & {$[1.70]$} & {$[2.68]$} & {$[0.57]$} \\
\hline \multirow[t]{2}{*}{$C r^{*} D(L L Y)$} & & -0.138 & $-0.503^{* * *}$ & & $-0.967^{* *}$ & $-1.561^{* * *}$ & & $0.183^{*}$ & $-0.317^{*}$ \\
\hline & & {$[-1.36]$} & {$[-12.26]$} & & {$[-2.26]$} & {$[-7.67]$} & & {$[1.96]$} & {$[-1.80]$} \\
\hline \multirow[t]{2}{*}{$C r^{*} D(B T O T)$} & & -0.076 & $4.897^{* *}$ & & -0.052 & $12.70^{* * *}$ & & $1.611^{*}$ & 0.358 \\
\hline & & {$[-0.26]$} & {$[2.39]$} & & {$[-0.18]$} & {$[11.25]$} & & {$[1.74]$} & {$[0.53]$} \\
\hline$C r^{*} D(M C A P)$ & & -0.011 & 0.033 & & -0.003 & -0.005 & & 0.034 & -0.085 \\
\hline & & {$[-0.55]$} & {$[1.57]$} & & {$[0.08]$} & {$[-0.17]$} & & {$[0.48]$} & {$[-0.31]$} \\
\hline$C r^{*} T O R$ & & $-0.016^{* *}$ & -0.007 & & -0.009 & $0.039^{* *}$ & & $-0.010^{* *}$ & -0.015 \\
\hline & & {$[-2.41]$} & {$[-1.46]$} & & {$[-1.09]$} & {$[2.46]$} & & {$[-2.25]$} & {$[-1.35]$} \\
\hline$C r^{*} I N F L$ & & -0.121 & $0.809^{* * *}$ & & -0.20 & -0.112 & & $-0.984^{* * *}$ & -0.020 \\
\hline & & {$[-0.34]$} & {$[4.28]$} & & {$[-1.24]$} & {$[-0.93]$} & & {$[-2.90]$} & {$[-0.02]$} \\
\hline$C r^{*} F D I$ & & -0.003 & $0.018^{* * *}$ & & -0.115 & $-0.104^{* * *}$ & & $-0.266^{* * *}$ & 0.319 \\
\hline & & {$[-1.66]$} & {$[4.59]$} & & {$[-1.27]$} & {$[-3.22]$} & & {$[-2.92]$} & {$[1.06]$} \\
\hline$C r^{*} D(O P E N)$ & & 0.045 & 0.028 & & 0.030 & 0.107 & & 0.129 & 0.199 \\
\hline & & {$[0.85]$} & {$[0.50]$} & & {$[0.52]$} & {$[1.63]$} & & {$[0.73]$} & {$[0.73]$} \\
\hline net effects & & & & & & & & & \\
\hline$L L Y$ & & n.a & -0.503 & & -0.967 & -1.561 & & 0.183 & -0.317 \\
\hline BTOT & & n.a & 4.897 & & 0.164 & 12.918 & & 2.078 & 0.559 \\
\hline$M C A P$ & & 0.040 & 0.026 & & n.a & n.a & & n.a & n.a \\
\hline TOR & & 0.006 & 0.007 & & n.a & 0.039 & & 0.002 & 0.010 \\
\hline$R^{2}$ & 0.287 & 0.417 & 0.511 & 0.173 & 0.375 & 0.462 & 0.254 & 0.521 & 0.337 \\
\hline obs & 228 & 228 & 228 & 214 & 214 & 214 & 119 & 119 & 119 \\
\hline
\end{tabular}

During the whole sample period and before the crisis periods, in the North-West panel, the financial stock market development indicators promoted growth, while in Central-Eastern and South panels the ratio of commercial bank assets prevailed. Also, in South countries the stock 
market liquidity contributed to economic growth.

During the ongoing crisis period, the adverse effect of liquid liabilities is from the group of transition economies, while in the sub-prime crisis period is from all panels. Also, in the subprime crisis period, the ratio of commercial banks assets have a positive and significant effect on economic growth in the North-West and Central Eastern panels.

The results from the net effects indicate that the stock market sector prevails in North-West countries, while for the other regional groups this is not the case. From the bank sector, the negative effect of liquid liabilities is found across all regional groups, while across all panels the effect of the ratio of commercial bank assets is positive.

The results confirm that markets have a greater contribution to the economic performances than the banks in North-West countries indicating that economic activities take place through organised markets. In Central-Eastern and South countries the banks' assets contributed to economic growth suggesting that the capital adequacy of banks ensured the stability of the financial system. Also, the major indicator of size relative to economy liquid liabilities, hindered economic growth during the subprime crisis period showing that any expansion of broad money as a share of GDP, has detrimental effects on economic growth ${ }^{5}$.

\section{Conclusions}

The results suggest that when the crisis period is not included, financial development promoted economic growth, while during the crisis periods has an adverse effect on economic activity. During the years 2008 and 2009, the findings suggest that the ratio of commercial bank assets kept the economy from falling out, implying that the capital adequacy of banks promoted the stability the financial system. Also, the results obtained in the subprime crisis period suggest that liquid liabilities hindered economic growth. Finally, the degree of international trade openness in the economy of a country was the primary factor that led growth during both crisis periods. Our findings call for a further investigation on the unconventional financial development measures that lead to economic growth after the crisis.

\footnotetext{
${ }^{5}$ See further details for additional results in appendix B
} 


\section{References}

Andreasen, E. and Valenzuela, P. (2016). Financial openness, domestic financial development and credit ratings, Finance Research Letters 16: 11 - 18.

Arestis, P., Demetriades, P. and Luintel, K. (2001). Financial development and economic growth: The role of stock markets, Journal of Money, Credit and Banking 33(1): 16-41.

Asongu, S. A., Le Roux, S. and Biekpe, N. (2017). Environmental degradation, ICT and inclusive development in Sub-Saharan Africa, Energy Policy 111: 353-361.

Asongu, S. and Nwachukwu, J. C. (2018). Openness, ICT and entrepreneurship in Sub-Saharan Africa, Information Technology \& People (just-accepted): 00-00.

Azman-Saini, Law, S. H. and Ahmad, A. H. (2010). FDI and economic growth: New evidence on the role of financial markets, Economics Letters 107(2): 211-213.

Brambor, T., Clark, W. R. and Golder, M. (2005). Understanding interaction models: Improving empirical analyses, Political analysis 14(1): 63-82.

Bumann, S., Hermes, N. and Lensink, R. (2013). Financial liberalization and economic growth: Ameta-analysis, Journal of International Money and Finance 33: 255-281.

Caporale, G., Rault, C., Sova, D. and Sova, R. (2015). Financial development and economic growth: Evidence from 10 new European Union members, International Journal of Finance and Economics 20(1): 48-60.

Demetriades (1996). Does financial development cause economic growth? Time-series evidence from 16 countries, Journal of Development Economics 51: 387-411.

Driscoll, J. and Kraay, A. (1998). Consistent covariance matrix estimation with spatially dependent panel data, The Review of Economics and Statistics 80(4): 549-560.

Levine, R. (1997). Financial development and economic growth: Views and Agenda, Journal of Economic Literature 35(2): 688-726.

Levine, R. (1999). Stock market development and long-run growth, World Bank Economic Review 10(2): 323-339. 
Levine, R. and Zervos, S. (1996). Stock market development and long-run growth, World Bank Economic Review 10(2): 323-339.

Samargandi, N., Fidrmuc, J. and Ghosh, S. (2015). Is the relationship between financial development and economic growth monotonic? Evidence from a sample of Middle-Income Countries, World Development 68(Supplement C): 66-81.

Shahbaz, M. (2012). Does trade openness affect long run growth? cointegration, causality and forecast error variance decomposition tests for Pakistan, Economic Modelling 29(6): 23252339.

Shahbaz, M., Kandil, M., Kumar, M. and Nguyen, D. K. (2017). The drivers of economic growth in China and India: Globalization or financial development?

Shahbaz, M., Rehman, I. U. and Muzaffar, A. T. (2015). Re-visiting financial development and economic growth nexus: The role of capitalization in Bangladesh, South African Journal of Economics 83(3): 452-471.

Tchamyou, V. S. and Asongu, S. A. (2017). Information sharing and financial sector development in Africa, Journal of African Business 18(1): 24-49. 


\section{Appendix A Data description}

Table A1: List of countries

\begin{tabular}{lll}
\hline \hline Panel A & Panel B & Panel C \\
\hline Austria & Bulgaria & Cyprus \\
Belgium & Croatia & Greece \\
Denmark & Czech Republic & Italy \\
Finland & Estonia & Spain \\
France & Hungary & Portugal \\
Germany & Latvia & \\
Ireland & Lithuania \\
Netherlands & Poland & \\
Sweden & Romania & \\
United Kingdom & Slovak Republic & \\
\hline Note: PANEL A includes the North-West EU countries. PANEL B in- \\
cludes the Central Eastern EU countries (transition economies). PANEL \\
C includes the South EU countries. Note that the countries Luxembourg \\
and Malta have population less than 500,000 in 1990 and are excluded \\
from the sample World Bank Global Development Network Database. \\
\hline \hline
\end{tabular}


Table A2: List of variables

\begin{tabular}{ll}
\hline \hline variables & \\
\hline GGDP & the annual percentage growth rate of Gross Domestic Product (GDP) \\
LLY & the ratio of liquid liabilities to GDP $(\%)$, also known as broad money or M3. They are the sum of currency \\
& and deposits in central banks (M0), plus transferable deposits and electronic currency (M1), plus time \\
& and saving deposits, foreign currency transferable deposits, certificates of deposits and securities of purchase \\
& agreements (M2), plus travelers checks, foreign currency time deposits, and shares of mutual funds or market \\
& funds held by residents. Liquid liabilities is one of the primary indicators used to measure the size, relative \\
& to the economy, financial intermediaries, including three types of financial institutions: the central bank, \\
& deposit money banks and other financial institutions. It is calculated as the liquid liabilities of banks and \\
& non-bank financial intermediaries over GDP.
\end{tabular}

BTOT the ratio of commercial bank assets to the sum of commercial bank plus central bank assets to GDP(\%). Commercial bank assets are the total assets held by deposit money banks and include the deposit money banks and other financial institutions that accept transferable deposits, such as demand deposits. It proxies the advantage of financial intermediaries in channelling savings to investments, monitoring firms, influencing corporate governance and undertaking risk management relative to the central bank.

MCAP the ratio of the total value of listed domestic shares in a stock market as an indicator of market size namely stock market capitalization to GDP (\%). Market capitalization (also known as market value) is the share price times the number of shares outstanding for listed domestic companies. Investment funds, unit trusts, and companies whose only business goal is to hold shares of other listed companies are excluded. The rational behind this measurement is the size of the stock market of the economy.

TOR the ratio of domestic shares traded on domestic exchanges during the period divided by the average market capitalization for the period, namely stock market turnover ratio. A high value of the turnover ratio will indicate a more liquid (and potentially more efficient) equity market.

INFL inflation rate as a proxy for macroeconomic stability

FDI net inflows of foreign direct investments to GDP(\%), which is the main channel of transmission from financial development to economic growth;

OPEN trade openness to GDP(\%), which is the sum of exports plus imports and measures the economic policies that either restrict or invite trade between countries; 


\section{Appendix B Additional results}

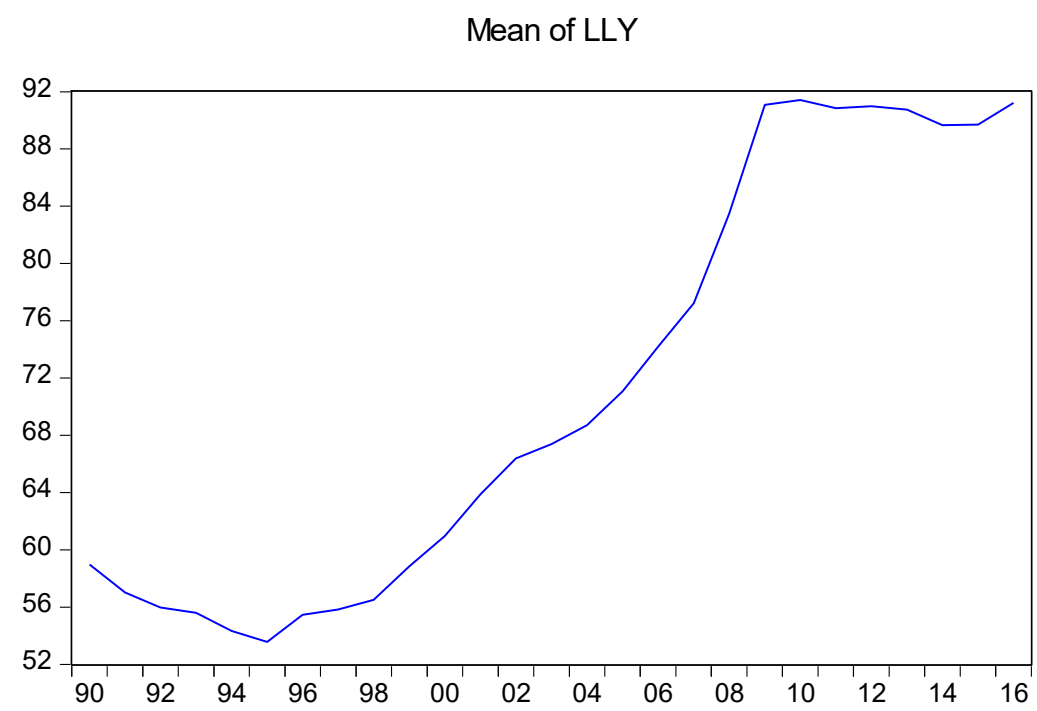

Figure B.1: The figure illustrates the mean of liquid liabilities, also known as broad money or M3, of 26 EU countries. There is an upward trend from 1995 to 2008, which approximately rises from $55 \%$ to more than $95 \%$. It is raised the question why increasing money supply across EU countries did not cause inflation rate, which tends to be close to $2 \%$ (see figure 2 ). The basic answer is that it depends on factors such as the velocity of circulation (number of times money changes hands), the condition of the economy and the growth in productivity (the Long Run Aggregate Supply LRAS). The growth of real output is supposed to increase at the same rate of money supply.

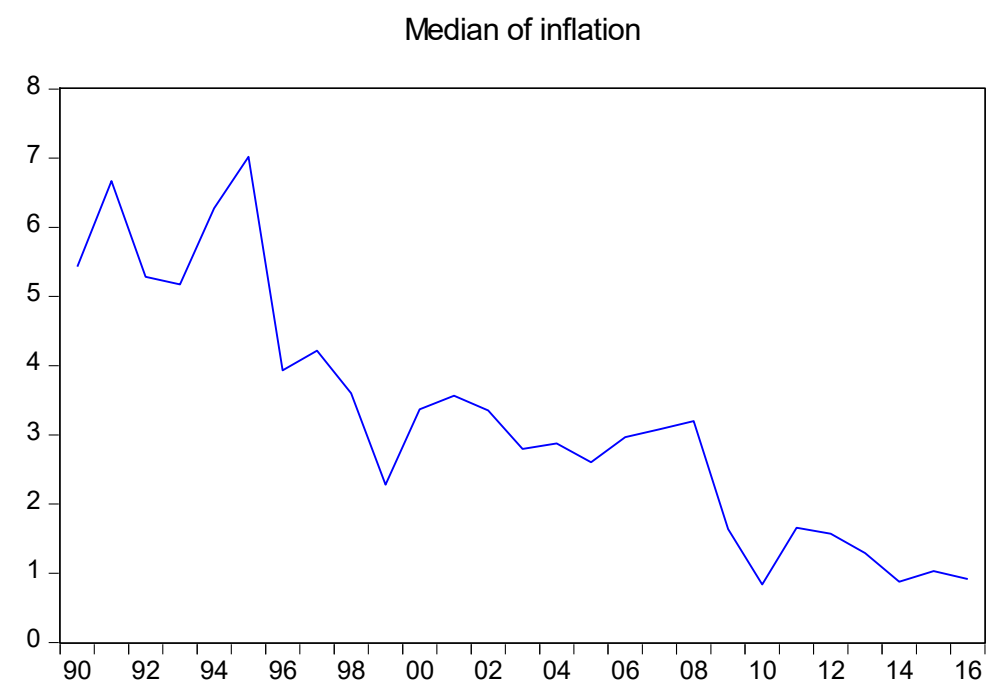

Figure B.2: This figure illustrates the median of inflation rate of $26 \mathrm{EU}$ countries. It declines from approximately $6 \%$ in 1990 to $2 \%$ in 2016. 


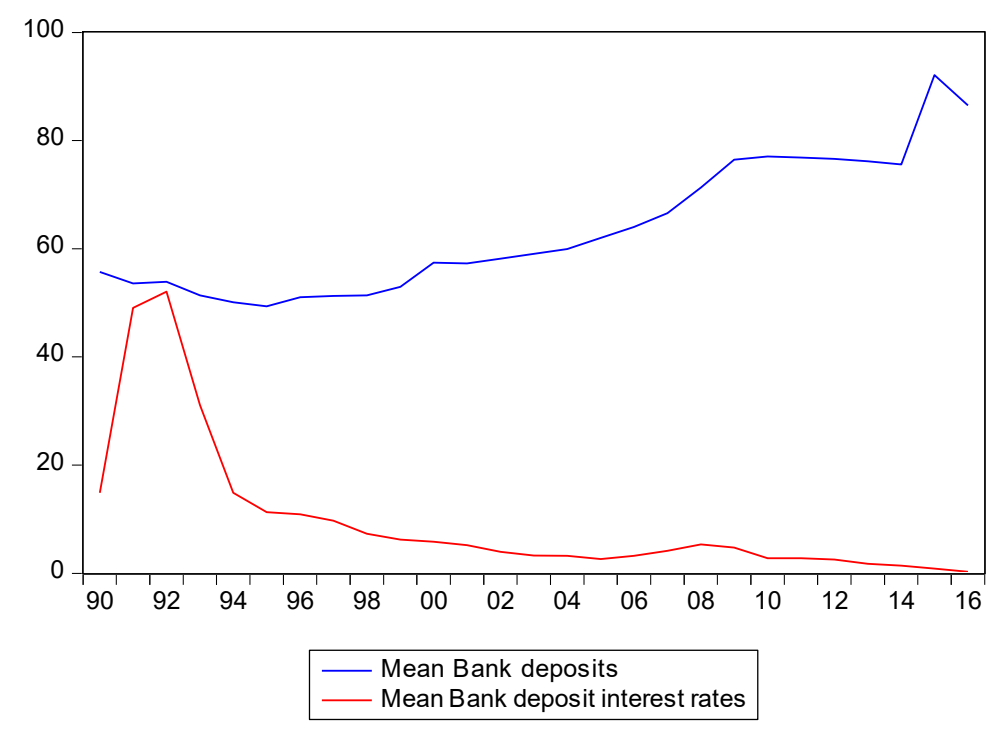

Figure B.3: This figure illustrates the mean of bank deposits and the mean of interest rates of bank deposits for the $26 \mathrm{EU}$ countries from 1990 to 2016. It is remarkable that while liquidity of money has an upward trend and interest rates tend to be close to zero, the bank deposits have been increased. Thus, consumers choose to avoid investing in bonds and keep their funds in deposits. However, in its original meaning by Keynes, while he has never used the word, the liquidity trap is the situation when investors have an abnormal preference over liquidity and prefer to keep their asset in the form of cash or demand deposit (Krugman, 1988). The common characteristics of a liquidity trap are low-interest rates (close to zero) and ineffective monetary policy. Thus, in a depressed economy (liquidity trap) is unlikely to cause inflation and there is a decrease in the velocity of circulation. 


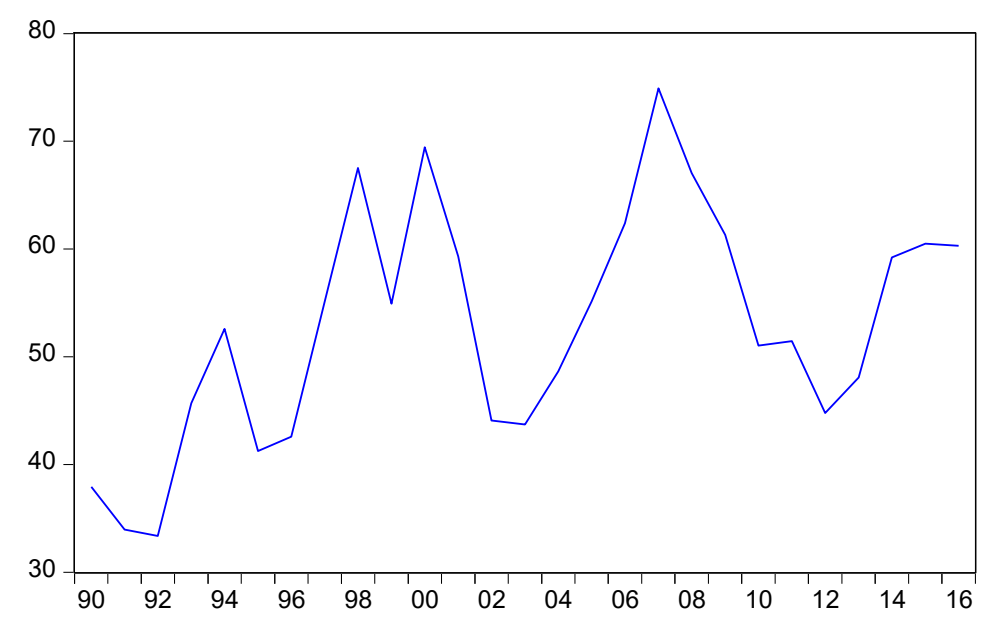

Figure B.4: This figure illustrates the mean of stock market turnover ratio for the 26 EU countries from 1990 to 2016. During the crisis, there is substantial evidence that the turnover ratio hindered growth. The permanent fall of the interest rate produced a temporary boom in investment as the industry moved to a permanently higher capital stock. The result was a high turnover ratio and the higher turnover ratio, the higher prices for the fund, which in turn drives to decreased returns for shareholders due to paying spreads and commissions when buying and selling stocks. The high cost is one of the most widely discussed negatives of high turnover ratio. Sometimes investors avoid investing directly in the companies because they cannot take back the amount of money that they spent at any time. But investing in the financial stock market, they can buy and sell stocks rapidly with more independence. 